\title{
The leukotriene-antagonist ICl-204,219 inhibits the early airway reaction to cumulative bronchial challenge with allergen in atopic asthmatics
}

\author{
B. Dahlén*, O. Zetterström*, T. Björck**, S-E. Dahlén**
}

The leukotriene-antagonist ICI-204,219 inhibits the early airway reaction to cumulative bronchial challenge with allergen in atopic asthmatics. B. Dahlén, O. Zetterström, T. Björck, S-E. Dahlén. CERS Journals Ltd 1994.

ABSTRACT: The hypothesis that cysteinyl-leukotrienes $\left(\mathrm{LTC}_{4}, \mathbf{L T D}_{4}\right.$ and $\left.\mathrm{LTE}_{4}\right)$ are mediators of allergen-induced airway obstruction in asthmatics was tested with the specific receptor antagonist ICI-204,219, in a double-blind, placebo-controlled, randomized, cross-over bronchoprovocation study.

On three occasions, cumulative bronchial challenge with specific allergen was performed in $\mathbf{1 0}$ males with mild allergic asthma. The first control session established the baseline provocative dose of allergen producing a decrease in forced expiratory volume in one second $\left(\mathrm{FEV}_{1}\right)$ by $20 \%\left(\mathrm{PD}_{20} \mathrm{FEV}_{1}\right)$. The two rechallenges were performed $2 \mathrm{~h}$ after oral administration of placebo or $20 \mathrm{mg}$ of ICI204,219.

The allergen dose-response relations were highly reproducible, producing $\mathbf{P D}_{20}$ values at the control session and after placebo treatment which varied by no more than 0.7-1.3 fold (95\% confidence interval $(95 \%$ CI)). After ICI-204,219, the median cumulated allergen dose was $\mathbf{5 . 5}$ fold higher, and the group geometric mean $\mathrm{PD}_{20}$ was increased 2.5 times. Furthermore, the recovery time after the immediate bronchoconstriction was shorter $(40 v s 60 \mathrm{~min})$. The wheal and flare responses to intradermally injected $\mathrm{LTD}_{4}$ were somewhat inhibited by ICI-204,219, whereas responses to histamine were unaffected. However, the findings suggest that skin testing with $\mathrm{LTD}_{4}$ is unlikely to predict the degree of leukotriene-antagonism in the airways.

The findings confirm and extend the indications that cysteinyl-leukotrienes are important mediators of allergen-induced airway obstruction, and that leukotrieneantagonists should be evaluated as a potential new therapy in allergic asthma. Eur Respir J., 1994, 7, 324-331.
*Asthma and Allergy Division, Dept of Thoracic Medicine, Karolinska Hospital, Stockholm, Sweden. **Dept of Physiology and Institute of Environmental Medicine, Karolinska Institutet, Stockholm, Sweden.

Correspondence: B. Dahlén

Dept of Thoracic Medicine

Karolinska Hospital

S-104 01 Stockholm

Sweden

Keywords: Atopic asthma, bronchial provocation test, ICI-204,219, leukotrienes, leukotriene receptor-antagonist, mediators in asthma

Received: January 211993

Accepted after revision August 81993

Supported by grants from the Swedish Medical Research Council (Project 14X09071), the Swedish Heart Lung Foundation, the Swedish Association Against Asthma and Allergy (RmA), the Swedish Environment Protection Board (31204), the Institute of Environmental Medicine, Karolinska Institutet and an operating grant from ICI (Zeneca) Pharmaceuticals. Parts of the data were presented in abbreviated abstract form at the VIIth International Congress of Prostaglandins and Related Compounds in Florence, 1990.
The leukotrienes (LT) comprise a group of arachidonic acid derivatives with the potential to function as mediators of pathophysiological events in asthma and other inflammatory diseases [1]. For example, $\mathrm{LTB}_{4}$, which is produced by cells of myeloid origin and probably mainly by polymorphonuclear leucocytes, is an effective chemotactic signal for leucocytes [2,3]. The cysteinylcontaining $\mathrm{LTC}_{4}, \mathrm{LTD}_{4}$ and $\mathrm{LTE}_{4}$, which also are formed in many cells including mast cells and eosinophils, are potent inducers of bronchoconstriction [4], plasma exudation [3], and mucus production [5]. Antigen challenge of lung tissue in vitro is associated with increased release of cysteinyl-leukotrienes [6]. Furthermore, the immunoglobulin ( $\mathrm{IgE}$ )-dependent contraction of isolated human bronchi has a major component that can be blocked by drugs which inhibit the production (inhibitors of 5lipoxygenase or its activation), or action (receptor antagonists), of leukotrienes [6-8]. These and other experimental findings have stimulated an interest in exploring the pos- sibility that leukotrienes are mediators of asthmatic responses in man.

Inhalation of cysteinyl-leukotrienes induces airway obstruction both in patients with asthma and volunteers, and asthmatics are generally hyperresponsive to these leukotrienes in comparison with nonasthmatics [9-12]. Furthermore, allergen provocation of atopic asthmatics is associated with the release of $\mathrm{LTE}_{4}$ into urine [13-18]. The urinary concentrations of $\mathrm{LTE}_{4}$ were also increased in asthmatics during episodes requiring hospital admission [13, 19]. The initial studies with leukotrieneantagonists in standard allergen provocations were not successful [20-22], but potency and bioavailability of the first drug candidates were rather limited. More recently, some members of the second generation of more potent receptor antagonists of the cysteinyl-leukotrienes have been reported to inhibit airway responses to inhaled allergen [23-25]. A low dose of the 5-lipoxygenase inhibitor, Zileuton, failed to cause significant inhibition 
of allergen-induced bronchoconstriction and excretion of urinary $\mathrm{LTE}_{4}$ [26], whereas the more potent inhibitor of leukotriene biosynthesis, MK-886, produced substantial inhibition of urinary $\mathrm{LTE}_{4}$ and of the allergen-induced airway obstruction in asthmatics [27].

The purpose of this study was to confirm earlier indications $[23,24]$ that the orally active and selective receptor antagonist of cysteinyl-leukotrienes, ICI-204,219 (Accolate) [28, 29], could inhibit allergen-induced airway obstruction in atopic asthmatics. We focused on the early airway reaction (EAR) and tested the effect of ICI-204,219 on the provocative dose (units) required to produce a decrease of forced expiratory volume in one second $\left(\mathrm{FEV}_{1}\right)$ by $20 \%\left(\mathrm{PD}_{20} \mathrm{FEV}_{1}\right)$, determined by cumulative challenge with increasing doses of allergen. It is expected that, in the presence of the receptor antagonist, a higher dose of the agonist is required to evoke the $20 \%$ decrease in $\mathrm{FEV}_{1}$, which would result in a displacement of the dose-response relation for allergen to the right. The displacement factor may be used as a quantitative measure of drug potency; enabling the protective effect of the antagonist on allergen-induced airway obstruction to be directly related to its potency as an antagonist of $\mathrm{LTD}_{4}$-induced bronchoconstriction. This approach has been used in studies with $\mathrm{H}_{1}$-receptor antagonists [30]. Another objective of the study was to evaluate whether skin responses to $\mathrm{LTD}_{4}$ could be used to estimate the degree of leukotriene-antagonism achieved by the particular dose $(20 \mathrm{mg})$ of ICI-204,219 used in this study.

\section{Methods}

\section{Patients}

Ten nonsmoking atopic men, with a history of asthma and with specific allergy to birch pollen, cat or dog dander, participated in the study. The study was approved by the Local Ethics Committee and the Swedish Drug Regulatory Agency (Läkemedelsverket). The patients gave informed consent. For inclusion in the study, bronchial reactivity to histamine was required, with a provocative concentration causing a $20 \%$ fall in $\mathrm{FEV}_{1}\left(\mathrm{PC}_{20}\right)$ of $<8.0 \mathrm{mg} \cdot \mathrm{ml}^{-1}$, determined as described elsewhere [31]. Their asthma was stable and $\mathrm{FEV}_{1} \geq 75 \%$ predicted at entry to the study. Patient characteristics are given in table 1.

\section{Study design}

All patients first underwent a control allergen bronchoprovocation, in order to demonstrate sensitivity of the airways to allergen, and to establish their $\mathrm{PD}_{20} \mathrm{FEV}_{1}$. Within four months of the control challenge (average interval 46 days, range 14-104 days) the double-blind, placebo-controlled, cross-over drug trial was started. On two separate days, the patients received either $20 \mathrm{mg}$ of ICI-204,219 or placebo tablets $2 \mathrm{~h}$ before allergen challenge. Patients always reported to the clinic at the same
Table 1. - Patient characteristics

\begin{tabular}{lccccc}
\hline $\begin{array}{l}\mathrm{Pt} \\
\text { No. }\end{array}$ & $\begin{array}{c}\text { Age } \\
\text { yrs }\end{array}$ & $\begin{array}{c}\mathrm{FEV}_{1} \\
\%\end{array}$ pred & $\begin{array}{c}\text { Histamine } \\
\mathrm{PC}_{20} \mathrm{mg} \cdot \mathrm{ml}^{-1}\end{array}$ & Allergen & $\begin{array}{c}\text { Medication } \\
\text { during study }\end{array}$ \\
\hline 1 & 28 & 92 & 4.00 & Cat & \\
2 & 34 & 105 & 0.55 & Cat & \\
3 & 28 & 102 & 1.10 & Cat & \\
4 & 28 & 101 & 3.20 & Cat & IB,IS \\
5 & 41 & 109 & 2.80 & Cat & \\
6 & 31 & 90 & 0.52 & Cat & \\
7 & 23 & 86 & 0.62 & Cat & IB,IS \\
8 & 56 & 88 & 0.30 & Birch & \\
9 & 26 & 86 & 1.35 & Dog & DSCG \\
10 & 42 & 77 & 0.62 & Dog & \\
\hline Mean & 34 & 94 & $1.06 *$ & & \\
Range & $23-56$ & $77-109$ & $0.3-4.0$ & & \\
\hline
\end{tabular}

$\mathrm{FEV}_{1}$ : forced expiratory volume in one second; $\mathrm{PC}_{20}$ : procative concentration of histamine causing a $20 \%$ fall in $\mathrm{FEV}_{1}$; Pt: patient; IB: inhaled beta-stimulant; IS: inhaled steroid; DSCG: inhaled disodium cromoglycate. *: geometric mean.

time of the day (i.e. 7:30 am). They were allowed a light breakfast while still at home. The two bronchoprovocations were separated by an interval of 2-6 weeks, and the same protocol for allergen dose increments was used at both occasions. For each challenge, the starting allergen dose was selected as $0.5-1 \log$ below the $\mathrm{PD}_{20} \mathrm{FEV}_{1}$ determined with the same protocol at the control session. The patients always returned to the clinic the morning after each treatment day for general follow-up, including physical examination, spirometry, and blood sampling for routine haematology and blood chemistry.

Throughout the study, patients continued their regular asthma therapy (table 1), except for withholding disodium cromoglycate and inhaled $\beta$-agonists for $8 \mathrm{~h}$ before a study day. Short-acting histamine $\mathrm{H}_{1}$-receptor antagonists were not allowed for $24 \mathrm{~h}$, and nonsteroidal antiinflammatory drugs (NSAIDs) were not allowed for 10 days prior to a challenge session.

\section{Allergen provocation and study day procedures}

Bronchoprovocation was performed by inhalation of allergen, using a dosimeter-controlled jet nebulizer (Spira Elektro 2, Respiratory Care Center, Finland and Alfax, Sweden [32]), to permit determination of $\mathrm{PD}_{20} \mathrm{FEV}_{1}$. Driven by compressed air at $7.5 \mathrm{l} \cdot \mathrm{min}^{-1}$, the nebulizer generated an aerosol with a mass-median particle aerodynamic diameter of $4.1 \mu \mathrm{m}$. With a $0.5 \mathrm{~s}$ nebulization period, the output was $7.1 \mu \mathrm{l}$ per breath. Pulmonary function was measured as $\mathrm{FEV}_{1}$ on a spirometer (Vitalograph MDI Compact, Förbandsmaterial, Sweden), and for monitoring of possible late asthmatic reactions (LARs) measurements of peak expiratory flow rate (PEFR) were obtained using a mini-Wright peak flow meter. Three concentrations of allergen extract, 1,000, 10,000 and 100,000 biological units $\cdot \mathrm{ml}^{-1}$, were prepared from powder dissolved in Pharmalgen albumin diluent. The extracts and the diluent were from Pharmacia AB, Uppsala, 
Sweden. By using the three concentrations, and by varying the number of breaths from the nebulizer, a protocol was developed creating approximately half-log increments in the cumulated dose of allergen $(7,21,71,213$, $710,2,130$ and 7,100 biological units). Baseline $\mathrm{FEV}_{1}$ was defined as the best of three recordings, 5 min apart. The challenge was started by inhalation of the diluent and, providing $\mathrm{FEV}_{1}$ did not change by more than $10 \%$, ICI-204,219 or placebo was ingested. Spirometry was obtained at 30, 60, 90 and 120 min after drug intake, the 120 min $\mathrm{FEV}_{1}$ value being used as baseline for the ensuing allergen challenge. Incremental doses of allergen were inhaled every 20 min until $\mathrm{FEV}_{1}$ had fallen by at least $20 \%$. Dose-response relations for the cumulated dose of allergen were constructed and the $\mathrm{PD}_{20} \mathrm{FEV}_{1}$ was determined by linear interpolation. After a positive reaction, spirometry was followed every 15 min until FEV had returned to within $10 \%$ of baseline, and thereafter hourly for up to $6 \mathrm{~h}$. The patients were asked to measure their PEFR hourly after discharge from hospital, until retiring to bed. The occurrence of a LAR was defined as a $15 \%$ drop in PEFR $3-12 \mathrm{~h}$ after the EAR.

\section{Skin tests}

Histamine $(10 \mathrm{nmol}), \mathrm{LTD}_{4}(0.1,1$ and $10 \mathrm{nmol})$ and saline were injected at the proximal parts of the volar aspects of the forearms in $50 \mu \mathrm{l}$ volumes, delivered by $0.3 \mathrm{ml}$ microfine insulin syringes (Benson-Dixon AB, Stockholm). The injections were made after the occurrence of the maximal airway response, i.e. 3-4 h after intake of placebo or active drug in the blinded sessions. The size of the wheal and flare responses were recorded at 5, 10, 20 and 30 min after injection, and delineated with a water-resistant fine-tip pen on a transparency sheet placed above the injected sites. The transparencies have been filed for documentation of the data. The injections and the skin monitoring were conducted by an investigator who was not involved in the bronchial provocation tests. The injection sites were monitored until the patients left the ward, usually about $4 \mathrm{~h}$ after the injection, and at the next morning visit (vide supra) the patients were asked about the occurrence of skin reactions during the night. After the experiments, the wheal and flare mean arithmetic diameter was calculated for each timepoint, by measurements of the vertical and perpendicular diameters in $\mathrm{mm}$. These measurements were made by an investigator who was unaware of the study code and who had not performed the skin tests. For evaluation, the wheal and flare responses to the injected substances were expressed as the sum of the respective measurements at the four time-points $(5,10,20$ and 30 min). Preliminary experiments indicated that this total index of the reactions gave information which was closely similar to the data obtained by planimetry and calculation of the area under the time-response curve. Histamine dihydrochloride was purchased from Sigma and dissolved in saline. Synthetic LTD $_{4}$ (GMP-grade) was purchased from Cascade Biochem Ltd (Berkshire, UK) and dilutions from a concentrated stock solution $(4.5 \mathrm{mM}$ in ethanol:water 1:1) were made in saline on each experimental day, according to a fixed protocol. The concentration of the stock solution was regularly checked by UV-spectrometry. The concentration of ethanol in the injected solutions was kept below $1 \%$, which had been shown to cause no skin reaction.

\section{Statistics}

Calculations of group mean and median $\mathrm{PD}_{20} \mathrm{FEV}_{1}$ values were performed on log transformed raw data. Analysis of variance was applied, and when data were found to be following a normal distribution pattern, the two-tailed paired Student's t-test was used to compare group means after placebo and active drug. Otherwise, the groups were compared with two-tailed Wilcoxon's paired test. Differences were considered to be significant when $\mathrm{p}$ was $<0.05$. The repeatability of the challenge procedure was evaluated by comparing logarithmically transformed $\mathrm{PD}_{20} \mathrm{FEV}_{1}$ values at control and placebo sessions, using the method described by Bland and Altman [33].

\section{Results}

\section{Bronchial challenge testing}

As a representative illustration of the findings in the study, the time-course of the airway response during the two blinded allergen-provocations are shown for subject No. 3 (fig. 1). Firstly, the baseline pulmonary function did not differ significantly between the two challenge sessions. For the group as a whole, the postdiluent FEV values, which were used as baseline before drug intake, were $4.1 \pm 0.6$ and $4.2 \pm 0.5 l($ mean \pm SD) on placebo and

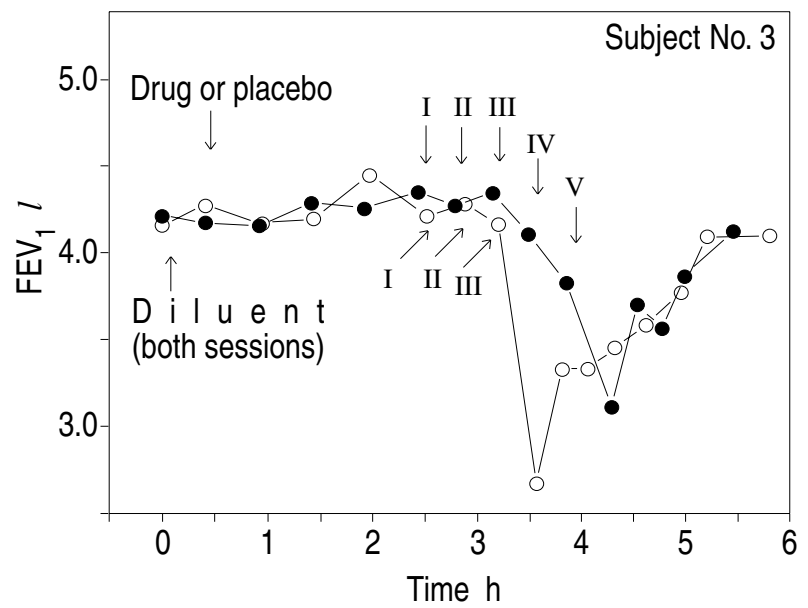

Fig. 1. - Time-course of allergen bronchoprovocation in subject No. 3 , on placebo and ICI-204,219 study days, respectively. Pulmonary function was followed as $\mathrm{FEV}_{1}$ over $6 \mathrm{~h}$. After inhalation of the diluent, either ICI-204,219 (20 mg) or placebo tablets were ingested, and $\mathrm{FEV}_{1}$ followed for $2 \mathrm{~h}$ before inhalation of cumulative doses of allergen commenced. Despite higher doses of allergen being administered on the ICI-204,219 study day (5 vs 3 doses), the maximal fall in FEV was lower and the time for recovery shorter. $\mathrm{FEV}_{1}$ : forced expiratory volume in one second. O-O: placebo; - - ICI-204,219. 

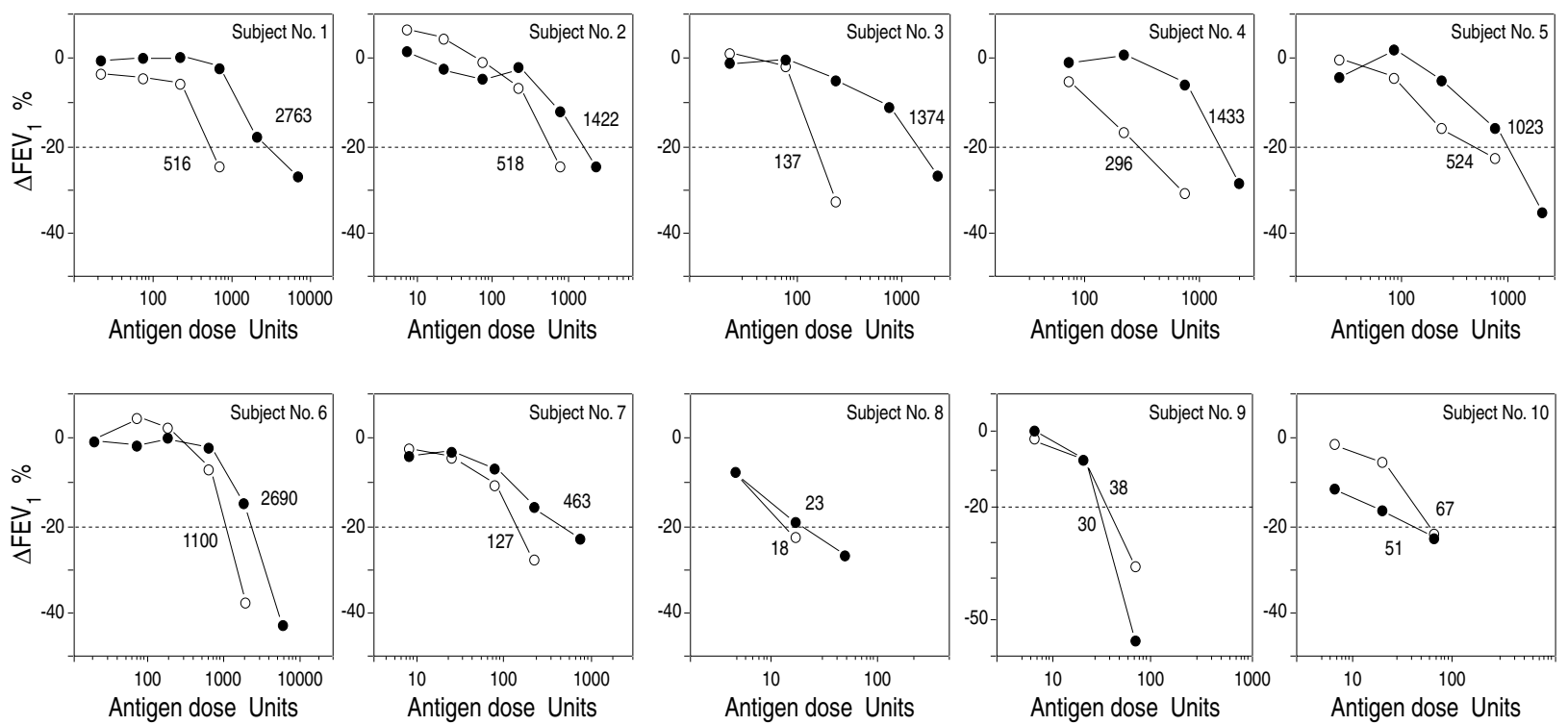

Fig. 2. - Dose-response relations for cumulative doses of inhaled allergen on placebo ( $\bigcirc-O)$ and ICI-204,219 (- subjects. Each point represents the percentage change in $\left.\mathrm{FEV}_{1}(\Delta \mathrm{FEV})_{1}\right)$ from prechallenge baseline after every dose (biological units) of inhaled allergen. The $\mathrm{PD}_{20} \mathrm{FEV}_{1}$ values, calculated from interpolation in each curve, are shown in the graphs. FEV $\mathrm{F}_{1}$ forced expiratory volume in one second; $\mathrm{PD}_{20} \mathrm{FEV}_{1}$ : provocative dose producing a $20 \%$ fall in $\mathrm{FEV}_{1}$.

ICI-204,219 treated days, respectively. Secondly, there was no significant change in $\mathrm{FEV}_{1}$ during the $2 \mathrm{~h}$ following ingestion of the active drug. For the group, $\mathrm{FEV}_{1}$ immediately before the start of challenge was $102 \pm 3 \%$ of baseline on the day active drug was given, as compared with $100 \pm 2 \%$ after placebo (mean $\pm \mathrm{SD}$ ).

Despite these similarities in baseline characteristics, the two challenge sessions were quite different, since one or two half-log increments in the dose of inhaled allergen (fig. 1) was usually required to decrease $\mathrm{FEV}_{1}$ by at least 20\% after ICI-204,219 (median allergen dose 2,130 (range 49-7,100) units) as compared with placebo (median allergen dose 389 (range 21-2,130) units). For the whole group there was a highly significant 5.5 fold increase in the median allergen dose after ICI-204,219.

Seven of the 10 subjects showed a clear-cut rightward shift of the dose-response relation for allergen in the presence of active drug (fig. 2). The mean shift in allergen $\mathrm{PD}_{20} \mathrm{FEV}_{1}$ for these seven subjects was 0.59 (range $0.29-1.00) \log$ units, corresponding to an approximately four fold increase (range 2-10 fold) in the presence of the leukotriene-antagonist. For the remaining three subjects, the difference in $\mathrm{PD}_{20}$ between placebo and active drug was within the expected range of variation between two allergen provocations $( \pm 0.12 \log$ units, vide infra). Nevertheless, for the group as a whole, there was a significant increase ( $\mathrm{p}=0.01$; Wilcoxon's paired test) in the $\mathrm{PD}_{20} \mathrm{FEV}_{1}$ for allergen in the presence of ICI-204,219 (fig. 3). Comparison of the geometric mean $\mathrm{PD}_{20} \mathrm{FEV}_{1}$ for the whole group on the two occasions, indicated a 2.5 fold increase in the $\mathrm{PD}_{20} \mathrm{FEV}_{1}$ for allergen after ICI204,219; 447 biological units after drug (95\% CI 177-1,738) and 180 units after placebo (95\% CI 71-468).

The three subjects (Nos 8-10) who did not respond to ICI-204,219 were those with the lowest $\mathrm{PD}_{20} \mathrm{FEV}_{1}$ for allergen, and they were also among the four with lowest $\mathrm{FEV}_{1} \%$ predicted. However, the differences between the subjects in this study with respect to disease parameters, such as histamine $\mathrm{PC}_{20}$, allergen $\mathrm{PD}_{20} \mathrm{FEV}_{1}$ and baseline $\mathrm{FEV}_{1} \%$ predicted, were quite small (table 1), possibly explaining why there were no clear correlations between the responses to the active drug and any of these parameters or their sum (Pearsons correlation coefficient $\mathrm{r} \leq 0.6 ; \mathrm{p}>0.1$ ).

The magnitude of the maximal EAR produced by the cumulative challenge was similar at the two sessions (drop in $\mathrm{FEV}_{1}$ being $32 \pm 11$ and $28 \pm 6 \%$ for active drug and placebo, respectively (mean $\pm \mathrm{SD}$ ); $\mathrm{p}>0.1$, Student's paired t-test). In contrast, the recovery phase, expressed

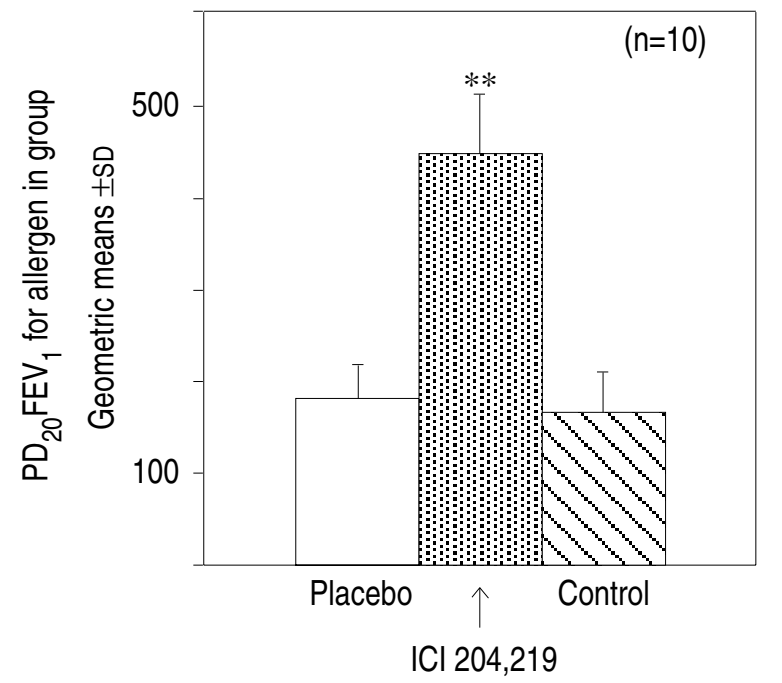

Fig. 3. - Group geometric mean \pm SD for allergen $\mathrm{PD}_{20} \mathrm{FEV}_{1}$ after treatment with placebo ( $\square$ ), ICI-204,219 ( control challenge $(\$)$. **: significant difference between placebo and ICI-204,219 ( $\mathrm{p}=0.01$; Wilcoxon's paired test). There was no difference in mean $\mathrm{PD}_{20} \mathrm{FEV}_{1}$ values between placebo and control sessions ( $\mathrm{p}=0.52$; Wilcoxon's paired test). For abbreviations see legend to figure 2 . 
as the time required for $\mathrm{FEV}_{1}$ to return from the peak drop to a value within $90 \%$ of the prechallenge baseline, was shorter in the group receiving ICI-204,219 (40 $\pm 11 \mathrm{~min}$ for active drug versus $60 \pm 26 \mathrm{~min}$ for placebo (mean $\pm \mathrm{SD})$; $\mathrm{p}<0.05$, Student's paired t-test.). Neither in the presence of placebo nor active drug was rescue treatment required during the EAR.

After being discharged from the clinic, the patients continued to record their PEFR and symptoms for up to $12 \mathrm{~h}$ after the provocation. Six LARs occurred in five of the subjects after one or both of the blinded sessions, with an equal distribution between placebo ( 3 out of 6 ) and active drug (3 out of 6).

There were no subjective or objective signs of drugrelated side-effects after this single $20 \mathrm{mg}$ dose of ICI204,219 .

\section{Repeatability}

As indicated in figure 3 , there was good agreement for the group as a whole between the $\mathrm{PD}_{20} \mathrm{FEV}_{1}$ values determined at the first control provocation and those obtained during the placebo session. The correlation between the individual $\mathrm{PD}_{20} \mathrm{FEV}_{1}$ values at the two sessions was indeed excellent (fig. 4a). Likewise, the group shift in $\mathrm{PD}_{20} \mathrm{FEV}_{1}$ values between the control and placebo session was negligible $(0.04 \pm 0.19 \mathrm{log}$ units as compared with $0.40 \pm 0.36 \log$ units between ICI-204,219 and placebo (means $\pm \mathrm{SD})$ ). When tested for repeatability according to BLAND and ALTMAN [33], by plotting logarithmically transformed $\mathrm{PD}_{20} \mathrm{FEV}_{1}$ values for the two sessions as the difference in results against their mean, it was further documented that the allergen provocation was highly repeatable (fig. 4b). Thus, in this group of 10 atopic men, the $95 \%$ CI obtained for the differences between the first control challenge and the challenge in the presence of placebo was $0.12 \log$ units, corresponding to an expected variation in $\mathrm{PD}_{20} \mathrm{FEV}_{1}$ which was no more than 0.7 - to 1.3- fold. This variation is less than previously reported for methacholine, with the same dosimeter [32].

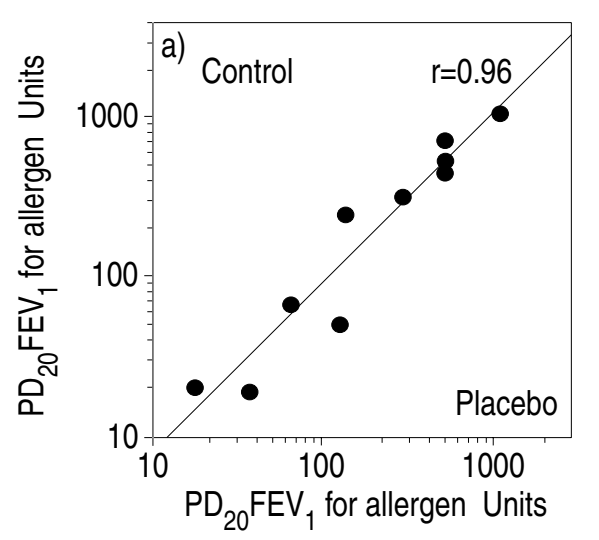

\section{Skin testing}

Intradermal injection of $\mathrm{LTD}_{4}$ produced a wheal and flare response, which was reproducible. For example, the wheal response to $1 \mathrm{nmol}$ of $\mathrm{LTD}_{4}$ was $40.6 \pm 4.0 \mathrm{~mm}$ at the control session and $39.8 \pm 4.6 \mathrm{~mm}$ after placebo (mean \pm SD), as compared with $57.8 \pm 13.3$ and $57.7 \pm 6.9$ for histamine $10 \mathrm{nmol}$ at the same two sessions. The flare evoked by $\mathrm{LTD}_{4}$ was consistently more pale than that produced by equi-active doses of histamine. The time course for the onset of the responses to histamine and $\mathrm{LTD}_{4}$ were, however, very similar, and neither compound caused a late cutaneous reaction. Histamine was more potent on a molar basis, but it was not possible to calculate a dose-ratio between the compounds from the present observations, because the dose-response curve for $\mathrm{LTD}_{4}$ was much shallower than that of histamine. In particular, there was no significant difference between the wheal responses to $0.1,1$ and $10 \mathrm{nmol}$ of $\mathrm{LTD}_{4}$ (fig. 5a), although all responses were significant compared with saline controls. The flare response to $\mathrm{LTD}_{4}$, however, showed some dose-dependency (fig. $5 b)$.

The wheal response to $\mathrm{LTD}_{4}$ was reduced by about $15 \%$ at each of the two highest dose levels after ICI204,219 (fig. 5a). The flare was inhibited by ICI-204, 219 to a slightly greater extent (20-30\%) (fig. 5b). For the flare, a mean rightward shift amounting to 0.43 log units could be calculated for the group as a whole (table 2). When analysed for the individual subjects, there was no correlation (Pearson correlation coefficient $\mathrm{r}=0.51 ; \mathrm{p}=0.13$ ) between the shift in the dose-response relation for $\mathrm{LTD}_{4}$ in the skin after ICI-204,219 and the shift in $\mathrm{PD}_{20} \mathrm{FEV}_{1}$ for allergen in the airways (table 2).

Skin responses to histamine were not inhibited by ICI204,219. The whealing produced by histamine $10 \mathrm{nmol}$ was $63.1 \pm 5.7 \mathrm{~mm}$ after ICI-204,219 and 57.7 $\pm 6.9 \mathrm{~mm}$ after placebo (mean $\pm \mathrm{sD}$; $\mathrm{p}>0.1$; Student's paired t-test). The corresponding values for the flare were 199.7 \pm 35.1 $\mathrm{mm}$ and 205.4 $\pm 25.9 \mathrm{~mm}$ ( $\mathrm{p}>0.1$; Student's paired t-test), respectively.

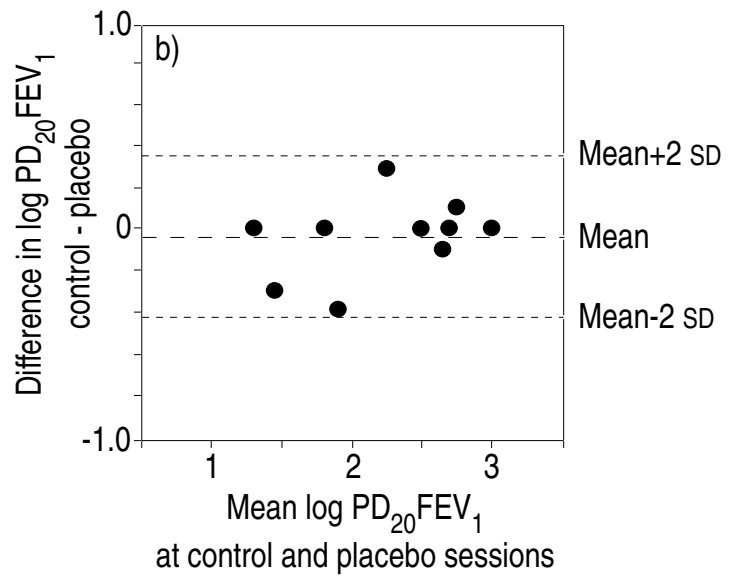

Fig. 4. - Illustration of the good repeatability of the allergen challenge in the study group. a) Correlation of the $\mathrm{PD}_{20} \mathrm{FEV}_{1}$ values at the control challenge and the placebo treated challenge for each subject. Pearson correlation coefficient $\mathrm{r}=0.96$ ( $\mathrm{p}=0.00001)$ for two-tailed probability of no correlation). b) The difference in $\log \mathrm{PD}_{20} \mathrm{FEV}_{1}$ between the two challenge sessions is plotted against their mean according to the method of Bland and Altman [33]. 

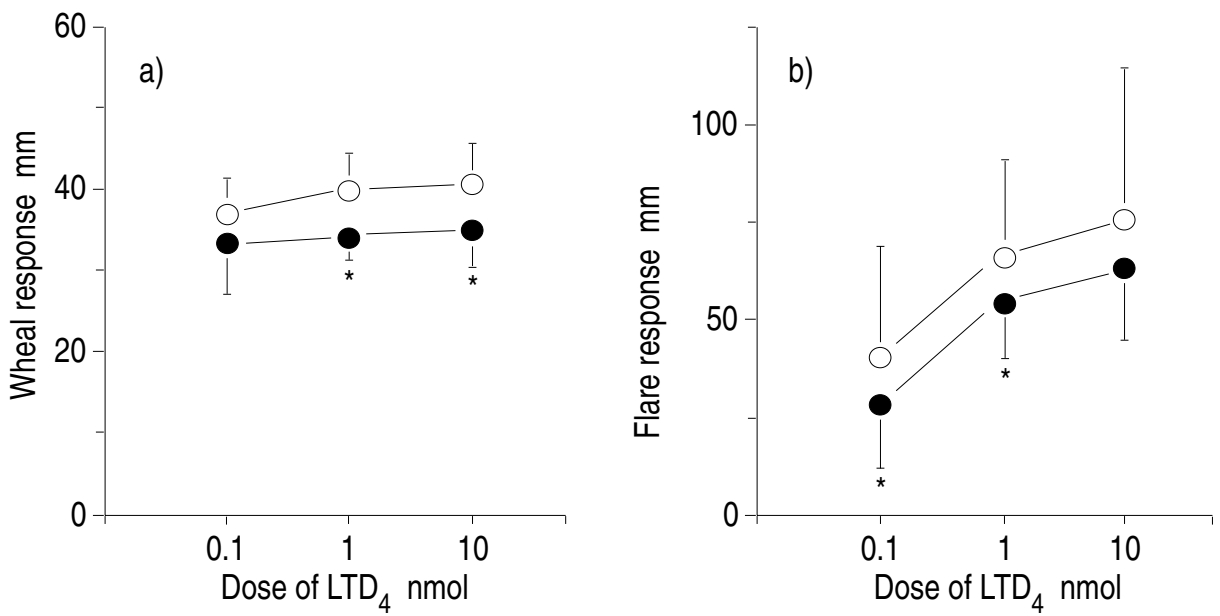

Fig. 5. - Dose-response relations a) for wheal and b) for flare reactions to intradermally injected leukotriene $\mathrm{D}_{4}\left(\mathrm{LTD}_{4}\right) 4 \mathrm{~h}$ after oral pretreatment with placebo or the leukotriene-antagonist ICI-204,219 $(20 \mathrm{mg})$. The global skin response was assessed as the sum of the mean arithmetic diameter of the respective responses at 5, 10, 20 and $30 \mathrm{~min}$ after injection. Mean \pm SD for all 10 subjects at each dose. *: significant difference between placebo and ICI-204,219 at this particular dose level ( $\mathrm{p}<0.05$ according to Student's two-tailed paired t-test). $\bigcirc-O$ : placebo; ICI-204,219.

Table 2. - Influence of $2 \mathrm{~h}$ oral pretreatment with 20 mg ICl-204,219 on airway response to allergen and skin response to $\mathrm{LTD}_{4}$

\begin{tabular}{lcc}
\hline $\begin{array}{l}\mathrm{Pt} \\
\text { No. }\end{array}$ & $\begin{array}{c}\text { Shift in } \mathrm{PD}_{20} \text { for allergen } \\
\log \text { units }\end{array}$ & $\begin{array}{c}\text { Shift in } \mathrm{LTD}_{4} \text {-flare } \\
\log \text { units }\end{array}$ \\
\hline 1 & 0.73 & 1.20 \\
2 & 0.44 & 0.70 \\
3 & 1.00 & 0.82 \\
4 & 0.69 & 0.58 \\
5 & 0.29 & -0.85 \\
6 & 0.39 & 0.45 \\
7 & 0.56 & 0.88 \\
8 & 0.11 & -0.20 \\
9 & -0.10 & 0.70 \\
10 & -0.11 & 0 \\
\hline Mean & 0.40 & 0.43 \\
Range & $-0.11-1.00$ & $-0.85-1.20$ \\
$95 \%$ CI & $0.14-0.66$ & $-0.01-0.86$ \\
\hline
\end{tabular}

The difference between active drug and placebo has been expressed as the logarithmic shifts in $\mathrm{PD}_{20} \mathrm{FEV}_{1}$ values for allergen and the dose-response relation for $\mathrm{LTD}_{4}$-induced flare, respectively. $\mathrm{PD}_{20} \mathrm{FEV}_{1}$ : provocative dose required to produce a $20 \%$ fall in $\mathrm{FEV}_{1}$; $\mathrm{LTD}_{4}$ : leukotriene $\mathrm{D}_{4}$; $90 \% \mathrm{CI}$ : $90 \%$ confidence interval.

\section{Discussion}

In this study, the competitive receptor antagonist of cysteinyl-leukotrienes, ICI-204,219 [28] caused substantial inhibition of several aspects of allergen-induced airway obstruction. For the group as a whole, ICI-204,219 caused a significantly higher mean $\mathrm{PD}_{20} \mathrm{FEV}_{1}$ value, as well as a higher total dose of allergen required to reach the predetermined level of bronchoconstriction. Despite this higher dose of allergen, the recovery after challenge was faster in the presence of the leukotriene-antagonist, and there was no increase in the occurrence of LARs.
The study thus documents that a lower dose $(20 \mathrm{mg})$ of ICI-204,219 than previously tested $(40 \mathrm{mg})[23,24]$ can inhibit allergen-induced bronchoconstriction. The reproducible and dose-dependent inhibition of various aspects of the airway responses to allergen-challenge in asthmatics by different second generation anti-leukotriene drugs ([23-25, 27], and this study), strongly supports that leukotrienes are significant mediators of allergen-induced airway obstruction in man.

The finding that ICI-204,219 increased the dose of allergen required to reach a defined response, is consistent with the mode of action of a specific receptor antagonist. In order to surmount the effect of the antagonist at the receptors for leukotrienes in the airways, more mediator must be released by increasing the stimulus for mediator release, i.e. the allergen dose. In fact, we have evidence supporting the fact that the higher doses of allergen after active drug were associated with increased formation of leukotrienes. Thus, in six of the subjects in this study, urinary $\mathrm{LTE}_{4}$ was followed as an index of pulmonary release of cysteinyl-leukotrienes [18]. The postchallenge increase in urinary $\mathrm{LTE}_{4}$ was consistently higher in the presence of ICI-204,219 as compared with placebo [18]. In contrast, neither ICI-204,219 nor another leukotriene-antagonist, MK-0679, by themselves, changed baseline prechallenge levels of urinary $\mathrm{LTE}_{4}$ $[18,34]$. Furthermore, when RASMUSSEN et al. [25] gave the same dose of allergen in the presence of placebo or the leukotriene-antagonist, MK-571, the postchallenge increase in urinary $\mathrm{LTE}_{4}$ was the same at both sessions [25]. On the other hand, using cumulative challenge, we recently observed that leukotriene-antagonism increased postchallenge urinary $\mathrm{LTE}_{4}$ and the $\mathrm{PD}_{20} \mathrm{FEV}_{1}$ for aspirin in aspirin-sensitive asthmatics [34]. Considered together, the information available, therefore, supports the notion that the extent of urinary excretion of $\mathrm{LTE}_{4}$ is directly dependent upon the intensity of the provocative stimulus.

The magnitude of the shift in allergen-dose after ICI204,219 corresponded to dose increments between 2.5 and 5.5 times for the group as a whole, depending upon 
how it was calculated $\left(\mathrm{PD}_{20} \mathrm{FEV}_{1}\right.$ or cumulated dose of inhaled antigen). When determined for the seven responders, the average effect of the antagonist was obviously larger. It is known that the dose of the antagonist used in this study should cause about a ten fold shift of the dose response relation for inhaled $\mathrm{LTD}_{4}$ at $12 \mathrm{~h} \mathrm{[35],}$ suggesting a higher degree of antagonism at $2 \mathrm{~h}$. Regrettably, it was not possible to determine the influence of this particular dose of ICI-204,219 on the bronchoprovocation response to $\mathrm{LTD}_{4}$ at $2 \mathrm{~h}$ in this study. However, an indirect attempt to estimate the extent of leukotriene-antagonism, we performed skin tests with $\mathrm{LTD}_{4}$ (see below).

It is difficult to know the reason(s) for the variability between the subjects in the effect of the leukotrieneantagonist on the airway response. One possibility is that the $20 \mathrm{mg}$ dose of ICI-204,219 was too low to provide significant antagonism of cysteinyl-leukotrienes in all subjects. However, in view of the high repeatability of the procedure employed for allergen-provocations, it is tempting to speculate that the variability in response to the active drug indicates subject heterogeneity with respect to the relative importance of the leukotrienes for the EAR. Possibly consistent with such a hypothesis, two out of the eight subjects in the study of TAYLOR et al. [23] were not protected by ICI-204,219, although the leukotriene-antagonist was used at a higher dose level. In isolated human bronchi, it is evident that cysteinylleukotrienes synergize with histamine as mediators of IgE-dependent contractions [7, 8, 36], presumably having a bearing on the EAR in atopic asthmatics. Bronchoprovocation studies using antihistamines have suggested that histamine mediates a significant component of the EAR [37]. However, since several of the antihistamines used in previous studies also display fairly significant activity as inhibitors of leukotriene release [38,39], the precise role of histamine in allergen-induced airway obstruction is not conclusively established.

The study also evaluated the possibility that the extent of leukotriene-antagonism could be estimated by performing skin tests with $\mathrm{LTD}_{4}$. This approach has been useful in studies of antihistamines [30]. It has been reported that the skin response to $\mathrm{LTD}_{4}$ is exceptionally variable [40], but with the procedure we used, the responses to $\mathrm{LTD}_{4}$ were as reproducible as those produced by histamine. For the group as a whole, ICI204,219 caused a 2.5 fold shift in the dose response relation for the $\mathrm{LTD}_{4}$-flare. There was a tendency that the subjects with the greatest antagonism of the skin response to $\mathrm{LTD}_{4}$ were also those where ICI-204,219 caused the largest displacement of the dose-response relation for allergen in the airways. Nevertheless, the degree of antagonism by ICI-204,219 of the skin response to $\mathrm{LTD}_{4}$ was not impressive, and was much less than has been reported for its effect on the bronchoprovocationresponse to $\mathrm{LTD}_{4}[29,35]$. In fact, a much less potent leukotriene-antagonist, LY-171,883, has been reported to cause a similar inhibition of the skin response to $\mathrm{LTD}_{4}$ [20]. Whether the relative inefficency of ICI-204,219 on the skin responses was due to differences in drug concentrations between the lung and the skin, or differ- ences in the receptor populations between the two tissues, remains to be determined. In summary, skin testing with $\mathrm{LTD}_{4}$ cannot be recommended as a means to estimate the degree of antagonism of $\mathrm{LTD}_{4}$ in the airways by a systemically administered receptor-antagonist.

In conclusion, the results of the present study support further evaluation of leukotriene-antagonism as a new strategy for inhibition of airway obstruction and inflammation in asthma. Future studies are required to evaluate the importance of this leukotriene component relative to other mediators of airway anaphylaxis, but, as discussed above, the role of histamine may have been overestimated by the unselective actions of antihistamines.

\begin{abstract}
Acknowledgements: The authors thank $\mathrm{H}$. Blomqvist and E. Eliasson for dedicated technical assistance, and R. Stark, S. Binks and J. Whitney of ICI (Zeneca) Pharmaceuticals in Alderly, UK and K. Boo of ICI (Zeneca) Pharmaceuticals in Sweden for kind help with different practical matters relating to this study.
\end{abstract}

\section{References}

1. Samuelsson B, Dahlén S-E, Lindgren JÅ, Rouzer CA, Serhan CN. Leukotrienes and lipoxins: structures, biosynthesis, and biological effects. Science 1987; 237: 1171-1176.

2. Ford-Hutchinson AW, Bray MA, Doig MV, Shipley ME, Smith MJH. Leukotriene $\mathrm{B}_{4}$, a potent chemokinetic and aggregating substance released from polymorphonuclear leukocytes. Nature 1980; 278: 456-459.

3. Dahlén S-E, Björk J, Hedqvist $\mathrm{P}$, et al. Leukotrienes promote plasma leakage and leukocyte adhesion in postcapillry venules: in vivo effects with relevance to the acute inflammatory response. Proc Natl Acad Sci USA 1981; 78: 3887-3891.

4. Dahlén S-E, Hedqvist P, Hammarström S, Samuelsson B. Leukotrienes are potent constrictors of human bronchi. Nature 1980; 288: 484-486.

5. Marom Z, Shelhamer JH, Bach MK, Morton DR, Kaliner M. Slow-reacting substances, leukotrienes $\mathrm{C}_{4}$ and $\mathrm{D}_{4}$, increase the release of mucus from human airways in vitro. Am Rev Respir Dis 1982; 126: 449-451.

6. Dahlén S-E, Hansson G, Hedqvist P, Björck T, Granström E, Dahlén B. Allergen challenge of lung tissue from asthmatics elicits bronchial contraction that correlates with the release of leukotrienes $\mathrm{C}_{4}, \mathrm{D}_{4}$ and $\mathrm{E}_{4}$. Proc Natl Acad Sci USA 1983; 80: 1712-1716.

7. Jones TR, Charette L, Denis D. Leukotriene and antiIgE induced contractions of human isolated trachea: studies with leukotriene receptor antagonists and a novel 5-lipoxy-genase inhibitor. Can J Physiol Pharmacol 1987; 66: 762-768.

8. Björck T, Dahlén S-E. Leukotrienes and histamine are the exclusive mediators of IgE-dependent contractions of human bronchi in vitro. Pulm Pharmacol 1993; 6: 87-96.

9. Smith LJ, Greenberger PA, Patterson R, Krell RD, Berstein PR. The effect of inhaled leukotriene $\mathrm{D}_{4}$ in humans. Am Rev Respir Dis 1985; 131: 368-372.

10. Bisgaard H, Groth S, Madsen F. Bronchial hyperreactivity to leukotriene $\mathrm{D}_{4}$ and histamine in exogenous asthma. Br Med J 1985; 290: 1468-1471. 
11. Ädelroth E, Morris MM, Hargreave FE, O'Byrne PM. Airway responsiveness to leukotrienes $\mathrm{C}_{4}$ and $\mathrm{D}_{4}$ and to methacholine in patients with asthma and normal controls. N Engl J Med 1986; 315: 480-484.

12. O'Hickey SP, Arm JP, Rees PJ, Spur BW, Lee TH. The relative responsiveness to inhaled leukotriene $\mathrm{E}_{4}$, methacholine and histamine in normal and asthmatic subjects. Eur Respir J 1988; 1: 913-917.

13. Taylor GW, Taylor I, Black P, et al. Urinary leukotriene $\mathrm{E}_{4}$ after antigen challenge and in acute asthma and allergic rhinitis. Lancet 1989; i: 584-588.

14. Tagari P, Rasmussen JB, Delorme D, et al. Comparison of urinary leukotriene $\mathrm{E}_{4}$ and 16-carboxytetranordihydro leukotriene $\mathrm{E}_{4}$ excretion in allergic asthmatics after inhaled allergen. Eicosanoids 1990; 3: 75-80.

15. Sladek K, Dworski R, Fitzgerald GA, et al. Allergenstimulated release of thromboxane $\mathrm{A}_{2}$ and leukotriene $\mathrm{E}_{4}$ in humans. Am Rev Respir Dis 1990; 141: 1441-1445.

16. Manning PJ, Rokash J, Malo J-L, et al. Urinary leukotriene $\mathrm{E}_{4}$ levels during early and late asthmatic responses. $J$ Allergy Clin Immunol 1990; 86: 211-220.

17. Westcott JY, Smith HR, Wenzel SE, et al. Urinary leukotriene $\mathrm{E}_{4}$ in patients with asthma. Am Rev Respir Dis 1991; 143: 1322-1328.

18. Kumlin M, Dahlén B, Björck T, Zetterström O, Granström $\mathrm{E}$, Dahlén S-E. Urinary excretion of leukotriene $\mathrm{E}_{4}$ and 11-dehydro-thromboxane $\mathrm{B}_{2}$ in response to bronchial provocations with allergen, aspirin, leukotriene $\mathrm{D}_{4}$ and histamine in asthmatics. Am Rev Respir Dis 1992; 146: 96-103.

19. Drazen JM, O'Brien J, Sparrow D, et al. Recovery of leukotriene $\mathrm{E}_{4}$ from the urine of patients with airway obstruction. Am Rev Respir Dis 1992; 146: 104-108.

20. Fuller RW, Black PN, Dollery CT. Effect of the oral leukotriene $\mathrm{D}_{4}$ antagonist LY-171,883 on inhaled and intradermal challenge with antigen and leukotriene $\mathrm{D}_{4}$ in atopic subjects. J Allergy Clin Immunol 1989; 83: 939-944.

21. Bel EH, Timmers MC, Dijkman JH, Stahl EG, Sterk PJ. The effect of an inhaled leuktriene antagonist, L-648,051, on early and late asthmatics reactions and subsequent increase in airway responsiveness in man. J Allergy Clin Immunol 1990; 85: 1067-1075.

22. Britton JR, Hanley SP, Tattersfield AE. The effect of an oral leukotriene $\mathrm{D}_{4}$ antagonist L-649,923 on the response to inhaled antigen in asthma. J Allergy Clin Immunol 1987; 79: 811-816.

23. Taylor IK, O'Shaoughnessy KM, Fuller RW, Dollery CT. Effect of cysteinyl-leukotriene receptor antagonist ICI 204,219 on allergen-induced bronchoconstriction and airway hyperreactivity in atopic subjects. Lancet 1991; 337: 690-694.

24. Findlay SR, Barden JM, Easley CB, Glass M. Effect of the oral leukotriene antagonist, ICI 204,219, on antigeninduced bronchoconstriction in subjects with asthma. $J$ Allergy Clin Immunol 1992; 89: 1040-1045.

25. Rasmussen JB, Eriksson LO, Margolskee DJ, Tagari P, Williams VC, Andersson KE. Leukotriene $\mathrm{D}_{4}$ receptor blockade inhibits the immediate and late bronchocon- strictor responses to inhaled antigen in patients with asthma. J Allergy Clin Immunol 1992; 90: 193-201.

26. Hui KP, Taylor IK, Taylor GW, et al. Effect of a 5lipoxygenase inhibitor on leukotriene generation and airway responses after allergen challenge in asthmatic patients. Thorax 1991; 46: 184-189.

27. Friedman BS, Bel EH, Tanaka W, Han YHR, Spector $\mathrm{R}$, Sterk P. The effect of a leukotriene biosynthesis inhibitor (MK-886) on allergen-induced bronchoconstriction and leukotriene production in asthmatic subjects. Am Rev Respir Dis 1993; 147: 839-844.

28. Krell RD, Aharony D, Buckner CK, et al. The preclinical pharmacology of ICI-204,219: a peptide leukotriene antagonist. Am Rev Respir Dis 1990; 141: 978-987.

29. Smith LJ, Geller S, Ebright L, Glass M, Thyrum PT. Inhibition of leukotriene $\mathrm{D}_{4}$-induced bronchoconstriction in normal subjects by the oral $\mathrm{LTD}_{4}$ receptor antagonist ICI-204,219. Am Rev Respir Dis 1990; 141: 988-992.

30. Town GI, Holgate ST. Comparison of the effect of loratadine on the airway and skin responses to histamine, methacholine, and allergen in subjects with asthma. J Allergy Clin Immunol 1990; 86: 886-893.

31. Ihre E, Zetterström O. Increase in nonspecific bronchial responsiveness after repeated inhalation of low doses of allergen. Clin Exp Allergy (in press).

32. Nieminen MM, Lahdensuo A, Kellomaeki L, Karvonen J, Muittari A. Methacholine bronchial challenge using a dosimeter with controlled tidal breathing. Thorax 1988; 43: 896-900.

33. Bland JM, Altman DG. Statistical methods for assessing agreement between two methods of clinical measurements. Lancet 1986; February 8: 307-310.

34. Dahlén B, Kumlin M, Margolskee DJ, et al. The leukotriene-receptor antagonist MK-0679 blocks airway obstruction induced by bronchial provocation with lysineaspirin in aspirin-sensitive asthmatics. Eur Respir J 1993; 6: 1018-1026.

35. Smith LJ, Glass M, Minkwitz MC. Inhibition of leukotriene $\mathrm{D}_{4}$-induced bronchoconstriction in subjects with asthma: a concentration effect study of ICI-204,219. J Clin Pharmacol Ther (in press).

36. Hay DWP, Muccitelli RM, Tucker SS, et al. Pharmacologic profile of SKF 104,353: a novel, potent and selective peptidoleukotriene receptor antagonist in guineapig and human airways. J Pharmacol Exp Ther 1987; 243: 474-481.

37. Rafferty P, Holgate ST. Histamine and its antagon-ists in asthma. J Allergy Clin Immunol 1989; 83: 537-547.

38. Temple DM, McCluskey M. Loratadine, an antihistamine, blocks antigen and ionophore-induced leukotriene release from human lung in vitro. Prostaglandins 1988; 35: 549-567.

39. Campbell AM, Chanez P, Marty-Ané C, et al. Modulation of eicosanoid and histamine release from human dispersed lung cells by terfenadine. Allergy 1993; 48: 125-129.

40. Greenberger PA, Smith LJ, Patterson R, et al. Comparison of cutaneous and bronchial reactivity to leukotriene $\mathrm{D}_{4}$ in humans. J Lab Clin Med 1986; 108: 70-75. 